\title{
Vitamin D Deficiency and Gestational Diabetes Mellitus in Egyptian Women
}

\author{
Ghada M. El-Sagheer'1, Asmaa Kasem¹, Iglal M. Shawky², Ahmed Abdel-Fadeel \\ ${ }^{1}$ Diabetes \& Endocrinology Unit, Internal Medicine Department, Minia University Hospital, Minia University, \\ El-Minia, Egypt \\ ${ }^{2}$ Internal Medicine Department, Minia University Hospital, Minia University, El-Minia, Egypt \\ ${ }^{3}$ Clinical Pathology Department, Minia University Hospital, Minia University, El-Minia, Egypt \\ Email: ghadagme70@yahoo.com
}

Received 27 January 2016; accepted 26 February 2016; published 29 February 2016

Copyright (C) 2016 by authors and Scientific Research Publishing Inc.

This work is licensed under the Creative Commons Attribution International License (CC BY). http://creativecommons.org/licenses/by/4.0/

(c) (i) Open Access

\section{Abstract}

Background: Although recent meta-analyses indicates a consistent significant inverse relation of serum $25(\mathrm{OH}) \mathrm{D}$ and the prevalence of gestational diabetes mellitus (GDM), the mechanism is unclear and conflicting opinions continue to be reported. Objectives: The objectives are: 1) comparison of vitamin D status in diabetic and non-diabetic pregnant women; 2) trying to determine the level of vitamin D associated with GDM, and its sensitivity and specificity; 3 ) determination of the relation of hypovitaminosis $D$ with insulin resistance. Subjects and Methods: One hundred consecutive pregnant women ( $<28$ weeks gestational period) from the attendants of the out-patient clinic at our hospital were diagnosed for GDM by glucose tolerance test (GTT) (75 g 2 h). Among them, 40 patients met the inclusion criteria for this study (group I). As a comparative group, another 40 pregnant ladies were included, 20 of them (group II) had pre-gestational type II DM, and the other 20 (group III) had normal glucose tolerance (NGT) as a control. For all the participants, we estimated fasting blood glucose, fasting serum insulin, homeostasis model assessment of (HOMA-IR and HOMA-B), quantitative insulin sensitivity check index (QUICKI), and serum 25-OH vit $D$. The ROC curve analysis was used to determine the optimal threshold value of vit $D$ in relation to DM. Results: Compared to the control group, the diabetic patients showed a statistically significant increase in the levels of fasting glucose, 1-hour postprandial glucose, 2-hour post prandial glucose, fasting insulin, and HOMA-IR, $(\mathrm{P}=0.000$ for all). None of the diabetic patients showed optimal vit D level. Vit D insuficiency $(10-29 \mathrm{ng} / \mathrm{ml})$ was found in $32.5 \%$ of patients in group I, $55 \%$ in group II, and $50 \%$ in group III. Vit D deficiency $(<10 \mathrm{ng} / \mathrm{ml})$ was found in $67.5 \%$ of patients in group I, $45 \%$ in group II, and $0 \%$ in group III. Significant negative correlation was found for vit $D$ with fasting insulin and FBS. The AUC for $250 \mathrm{H}$ vit D was $97 \%$, CI was $95 \%$ and p-value was 0.0001. The sensitivity, specificity, and positive and negative predictive values of $25 \mathrm{OH}$ vit $\mathrm{D}$ in GDM versus control persons were $97 \%, 90 \%, 95.1 \%, 94.7 \%$ respectively at a cut-off level $<22$ $\mathrm{ng} / \mathrm{ml}$. Conclusions: Although it might seem premature to draw a sharp relation between hypovi- 
taminosis D and GDM, this study showed the importance of vit D in GDM, the need for supplementation below $22 \mathrm{ng} / \mathrm{ml}$, and the role of hypovitaminosis $D$ in increasing insulin resistance. Further randomized studies with vit $\mathrm{D}$ supplementation are recommended.

\author{
Keywords
}

\title{
Gestational Diabetes Mellitus, Glucose Intolerance, Vitamin D
}

\section{Introduction}

Although, recent evidence suggests that vitamin D deficiency may contribute to the development of type II diabetes mellitus (T2DM), the exact mechanism is unknown [1] [2]. The prevalence of GDM is increasing, reached almost 15\% - 20\% [3]. Unmanaged gestational diabetes increases the risk of developing T2DM after pregnancy and predisposes the offspring to childhood obesity and T2DM later in life [4]. Compelling evidence suggests a role of vitamin D deficiency in the pathogenesis of insulin resistance and insulin secretion derangements. The coexistence of insulin resistance and vitamin D deficiency has generated several hypotheses as worsening insulin resistance [5]. Immense interest persists in vitamin D and its potential effects on several pregnancy outcomes including gestational diabetes mellitus (GDM) [6]. Although vitamin D deficiency during pregnancy reached 40\% - 100\% in some countries, no similar studies about Egyptian females were done [7]-[11]. Vitamin D deficiency appears to be associated with altered glucose homeostasis during pregnancy [12] [13]. Although [1.25 (OH) D] supplementation was reported to decrease glucose and increase insulin levels [14], other studies found no significant differences in vitamin D status between women with GDM and NGT [15] [16]. Emerging evidence suggests that vitamin $\mathrm{D}$ administration can improve insulin sensitivity and glucose tolerance, but whether vitamin D supplementation can prevent GDM is unknown [17]. Although, vitamin D deficiency is associated with a higher risk of GDM, conflicting evidence is provided as to whether low serum 25-hydroxyvitmain D (25 (OH) D) levels are associated with GDM. Therefore, we conducted this study for:

- Comparison of vit D status in pregnant women;

- Trying to determine the level of vitamin D associated with GDM, and its sensitivity and specificity;

- Determination of the relation of hypovitaminosis D with insulin resistance.

\section{Material and Methods}

After approval of the local health ethical committee and a written consent, we conducted an observational case control study on pregnant women attending the out-patient clinic at our hospital between September 2013 to September 2015. The inclusion criteria were pregnant ladies $<28$ weeks gestational age. The exclusion criteria included previous history of GDM or obstetric complications, metabolic bone disease, abnormal liver function, impaired kidney function, or patients receiving medication known to affect calcium \& vit D metabolism (except routine prenatal vitamin supplements including calcium). One hundred consecutive pregnant women with GDM were studied. From them, only 40 patients met the inclusion criteria for this study (group I). As a comparative group, another 40 pregnant ladies were included, 20 of them (group II) had pre-gestational type II DM, and the other 20 (group III) had normal glucose tolerance (NGT) as a control. The glucose tolerance test (GTT) (75 g 2 h) was used to diagnose GDM according to the guidelines of the international association of diabetes and pregnancy study groups (IADPSG) 2010. The diagnosis was confirmed when the plasma glucose level exceeded: fasting: $\geq 92 \mathrm{mg} / \mathrm{dL}(5.1 \mathrm{mmol} / \mathrm{L}), 1 \mathrm{~h}: \geq 180 \mathrm{mg} / \mathrm{dL}(10.0 \mathrm{mmol} / \mathrm{L}), 2 \mathrm{~h}: \geq 153 \mathrm{mg} / \mathrm{dL}(8.5 \mathrm{mmol} / \mathrm{L})$.

All the participants were subjected to:

- Full history taking including gestational age, history of previous GDM, family history of diabetes and history of maternal and neonatal complications;

- Thorough clinical examination including assessment of blood pressure, calculation of the body mass index (BMI), and obesity was defined as BMI $>30 \mathrm{~kg} / \mathrm{m}$ and morbid obesity $>40 \mathrm{~kg} / \mathrm{m}^{2}$;

- Laboratory assay including fasting blood glucose, fasting serum insulin, homeostasis model assessment of insulin resistance and $\beta$ cell function (HOMA-IR \& HOMA-B), quantitative insulin sensitivity check index (QUICKI), and serum 25-OH vit D. The HOMA-IR was calculated by multiplying fasting plasma insulin 
(FPI) $\mathrm{mU} / \mathrm{mL}$ by fasting plasma glucose $(\mathrm{FPG}) \mathrm{mmol} / \mathrm{L}$, then dividing by the constant 22.5, i.e. HOMA-IR = $($ FPI $\times$ FPG $) / 22.5$. HOMA-IR values $<3.0$ are considered normal, while values $\geq 3.0$ indicate insulin resistance. The HOMA-B was calculated as (FPI in $\mathrm{mU} / \mathrm{mL} \times 20) /(\mathrm{FPG}$ in $\mathrm{mmol} / \mathrm{L}-3.5)$. The QUICKI was calculated by the formula (1/log FPI in $\mathrm{mU} / \mathrm{mL}+\log$ FPG in $\mathrm{mg} / \mathrm{dl}$ ) vitamin $\mathrm{D}$ sufficiency, insufficiency, and deficiency were defined as serum 25OHD concentrations $30-100,10-29$ and $<10 \mathrm{ng} / \mathrm{mL}$ respectively.

\section{Statistical Analysis}

Data was collected and included in a data based system and analyzed by statistical package of social sciences ((SPSS, Inc., Chicago, IL, USA)) version 17. Parametric data were expressed as mean \pm standard deviation (SD). It was analyzed statistically using student t-test while non-parametric data were expressed as percentages and were analyzed using chi square. The Pearson correlation coefficients (r) were used to study the correlation between different parametric variables. Spearman correlation coefficients were used to study the correlation with non-parametric variables. Logistic regression analysis was done to calculate the odds ratio to determine the contribution of some variables to gestational diabetes. Receiver operating characteristics (ROC) analysis was used to identify the optimal threshold values of $25 \mathrm{OH}$ vitamin D. Sensitivity and specificity, positive and negative predictive values of $25(\mathrm{OH})$ vitamin $\mathrm{D}$ were profiled by curves.

\section{Results}

Table 1 shows the demographic and clinical, biochemical characteristics among the study groups and their statistical significance. There was a significant increase in systolic and diastolic blood pressure $(P=0.00,0.05)$, BMI, family history of diabetes, $(\mathrm{P}<0.5)$ noticed in comparing the diabetic groups (gestational and pre gestational) in relation to control group. A statistically significant increase was detected in FBS, 1-H glucose, 2-H glucose, fasting insulin, (HOMA-IR), HbA1c, $(\mathrm{P}=0.00)$. A statistically significant decrease in vitamin $\mathrm{D}$ serum level and in diabetic groups compared to control group $(\mathrm{P}=0.00)$, A significant decrease in total and ionized calcium and QUICKI in diabetic groups compared to control group $(\mathrm{P}=0.00)$.

Table 2 and Figure 1 show that no patient in the diabetic groups has the optimal vitamin D level. Insufficient vitamin D levels were found in 32.5\% of GDM, 55\% of diabetic and 50\% of control group (10 - $29 \mathrm{ng} / \mathrm{ml})$. Sever form of vitamin D deficiency in $67.5 \%$ of GDM and $45 \%$ of diabetic group $(\mathrm{P}=0.00)$. $50 \%$ of control group has optimal level.

In the GDM group, serum $25(\mathrm{OH})$ vit $\mathrm{D}$ had a significant negative correlation with BMI, fasting insulin $(\mathrm{P}=$ $0.00,0.05$ respectively), and tendency towards significant positive correlation with HOMA-B $(\mathrm{P}=0.09)$. In the diabetic group; serum $25(\mathrm{OH})$ vit $\mathrm{D}$ had a highly significant negative correlation with CRP $(\mathrm{P}=0.00)(\mathrm{Table} 3$ \& Figure 2). HOMA-IR has a positive correlation with FBS in both diabetic groups ( $\mathrm{P}=0.05$, 0.01 respectively), a positive correlation with 2-H glucose in GDM, $(\mathrm{P}=0.03)$ (Table 4). The relative risk for developing GDM was higher with increasing systolic and diastolic blood pressure, triglycerides, total cholesterol, low density lipoprotein, body mass index and C-reactive protein with odds ratio $(1.07,1.06,1.04,1.21,1.17,1.93$ and 1.04 respectively) ( $\mathrm{P}=0.00,0.02,0.01)$ and confidence interval 95\%. When all patients with GDM were evaluated, the AUC for $25 \mathrm{OH}$ vitamin D was (0.97), CI was (0.95\%), and p-value $=0.0001$ (Figure 3). The sensitivity, specificity, positive predictive value (PPV) and negative predictive value (NPV) of $25 \mathrm{OH}$ vitamin D levels in GDM patients relative to the control group were $97.5 \%, 90 \%, 95.1 \%$, and $94.7 \%$ respectively) at a cut-off value of $\leq 22 \mathrm{ng} / \mathrm{ml}$ (Table 5).

\section{Discussion}

The main limitations for this study included the small number of patients and absence of evaluation for the effect of vit D supplementation. Controversy still exists about the exact role of vit. D deficiency in the pathogenesis of DM, especially, GDM. Many previous studies [18] [19] reported high prevalence of vitamin D deficiency that reached approximately 95\% among both pregnant and non-pregnant women. Even in the sunny-Egypt, we also found high prevalence of vitamin D deficiency especially during pregnancy. This may be explained by poor sun exposure, poor dietary intake, and lack of physical activity.

Race/ethnicity is an important determinant of vitamin D deficiency. Yu et al. [20] studied 180 pregnant women of four ethnic groups and compared their serum 25-hydroxyvitamin D at gestational week 27. They 
Table 1. Demographic and clinical characteristics metabolic factors, 25 hydroxy vitamin D, CRP level among the study groups and their statistical significance.

\begin{tabular}{|c|c|c|c|c|c|c|}
\hline \multirow{2}{*}{ Variables } & \multirow{2}{*}{$\begin{array}{c}\text { Group (1) } \\
\text { ladies } \\
\text { With GDM } \\
\text { NO (40) }\end{array}$} & \multirow{2}{*}{$\begin{array}{c}\text { Group (2) } \\
\text { Ladies With pre } \\
\text { gestational } \\
\text { DM, NO (20) }\end{array}$} & \multirow{2}{*}{$\begin{array}{c}\text { Group (3) } \\
\text { Ladies As normal } \\
\text { control NO (20) }\end{array}$} & \multicolumn{3}{|c|}{$P$ value } \\
\hline & & & & 1 & 2 & 3 \\
\hline Age (years) mean $\pm \mathrm{SD}$ & $27.8 \pm 5.39$ & $30.8 \pm 6.62$ & $26.63 \pm 5.67$ & $0.254^{\#}$ & $0.557^{\#}$ & $0.632^{\#}$ \\
\hline $\begin{array}{l}\text { Gestational age (wk) } \\
\text { Mean } \pm \text { SD }\end{array}$ & $34.5 \pm 2.96$ & $30 \pm 4$ & $30.42 \pm 4.18$ & $0.340^{\#}$ & $0.276^{\#}$ & $0.541^{\#}$ \\
\hline Gravity mean \pm SD & $3.22 \pm 1.77$ & $4.05 \pm 2.08$ & $3.57 \pm 1.67$ & $0.462^{\#}$ & $0.441^{\#}$ & $0.140^{\#}$ \\
\hline Parity mean \pm SD & $1.47 \pm 1.53$ & $1.95 \pm 1.9$ & $2.21 \pm 1.43$ & $0.080^{\#}$ & $0.632^{\#}$ & $0.340^{\#}$ \\
\hline FH of DM (yes/No) \% & (30/10) $7 \%$ & (13/7) 65\% & (0/20) $0 \%$ & $0.000^{* *}$ & $0.000^{* *}$ & $0.000^{* *+}$ \\
\hline $\mathrm{SBP}(\mathrm{mmHg})$ mean $\pm \mathrm{SD}$ & $126.75 \pm 17.3$ & $122.5 \pm 24.03$ & $109.73 \pm 15.49$ & $0.001^{* *}$ & $0.05^{*}$ & $0.487^{\#}$ \\
\hline $\mathrm{DBP}$ (mmHg) mean \pm SD & $78.13 \pm 14.26$ & $78 \pm 11.965$ & $70 \pm 8.81$ & $0.010^{* *}$ & $0.023^{*}$ & $0.972^{\#}$ \\
\hline $\begin{array}{c}\text { Pre preg BMI }\left(\mathrm{kg} / \mathrm{m}^{2}\right) \\
\text { mean } \pm \mathrm{SD}\end{array}$ & $31.01 \pm 3.73$ & $29.26 \pm 4.18$ & $23.05 \pm 2.51$ & $0.000^{* *}$ & $0.000^{* *}$ & $0.123^{\#}$ \\
\hline $\mathrm{TG}(\mathrm{mg} / \mathrm{dl})$ mean $\pm \mathrm{SD}$ & $179.7 \pm 78.73$ & $188.4 \pm 97.7$ & $103.57 \pm 25.28$ & $0.000^{* *}$ & $0.001^{* *}$ & $0.734^{\#}$ \\
\hline $\begin{array}{c}\text { T-Chol }(\mathrm{mg} / \mathrm{dl}) \\
\text { mean } \pm \mathrm{SD}\end{array}$ & $191.8 \pm 58.23$ & $186.9 \pm 37.48$ & $86.84 \pm 18.87$ & $0.000^{* *}$ & $0.000^{* *}$ & $0.698^{\#}$ \\
\hline $\begin{array}{l}\text { HDL-Chol }(\mathrm{mg} / \mathrm{dl}) \\
\text { mean } \pm \mathrm{SD}\end{array}$ & $42.9 \pm 10.62$ & $44.6 \pm 15.19$ & $59.63 \pm 15.79$ & $0.104^{\#}$ & $0.318^{\#}$ & $0.657^{\#}$ \\
\hline $\begin{array}{l}\text { LDL-Chol }(\mathrm{mg} / \mathrm{dl}) \\
\text { mean } \pm \mathrm{SD}\end{array}$ & $122.79 \pm 56.73$ & $114.57 \pm 31.32$ & $26.03 \pm 9.06$ & $0.000^{* *}$ & $0.000^{* *}$ & $0.473^{\#}$ \\
\hline $\begin{array}{l}\text { Total Ca }(\mathrm{mg} / \mathrm{dl}) \\
\text { mean } \pm \mathrm{SD}\end{array}$ & $8.23 \pm 1.71$ & $8.07 \pm 1.7$ & $9.87 \pm 0.627$ & $0.000^{* *}$ & $0.000^{* *}$ & $0.740^{\#}$ \\
\hline $\begin{array}{c}\text { Ionized } \mathrm{Ca}(\mathrm{mmol} / \mathrm{l}) \\
\text { mean } \pm \mathrm{SD}\end{array}$ & $0.9 \pm 0.157$ & $0.92 \pm 0.105$ & $1.19 \pm 0.086$ & $0.000^{* *}$ & $0.000^{* *}$ & $0.572^{\#}$ \\
\hline FBS $(\mathrm{mg} / \mathrm{dl})$ mean $\pm \mathrm{SD}$ & $112.4 \pm 14.63$ & $120.65 \pm 14.47$ & $81.73 \pm 6.14$ & $0.000^{* *}$ & $0.000^{* *}$ & $0.046^{*}$ \\
\hline $\begin{array}{c}1 \text { hour glucose }(\mathrm{mg} / \mathrm{dl}) \\
\text { mean } \pm \mathrm{SD}\end{array}$ & $204.45 \pm 30.91$ & $237.95 \pm 32.95$ & $158.57 \pm 13.47$ & $0.000^{* *}$ & $0.000^{* *}$ & $0.001^{*+*}$ \\
\hline $\begin{array}{l}2 \text { hour glucose }(\mathrm{mg} / \mathrm{dl}) \\
\text { mean } \pm \mathrm{SD}\end{array}$ & $160.65 \pm 20.11$ & $177.95 \pm 18.36$ & $128.42 \pm 13.88$ & $0.000^{* *}$ & $0.000^{* *}$ & $0.002^{*}$ \\
\hline HbA1C (\%) mean \pm SD & $6.79 \pm 0.53$ & $9.15 \pm 6.1$ & $6.11 \pm 0.26$ & $0.000^{* *}$ & $0.038^{*}$ & $0.101^{\#}$ \\
\hline $\begin{array}{l}\text { Fasting insulin }(\mu \mathrm{u} / \mathrm{ml}) \\
\text { mean } \pm \mathrm{SD}\end{array}$ & $45.35 \pm 22.75$ & $39.8 \pm 29.43$ & $10.58 \pm 2.65$ & $0.000^{* *}$ & $0.000^{* *}$ & $0.465^{\#}$ \\
\hline HOMA-IR mean \pm SD & $1.79 \pm 0.75$ & $1.81 \pm 0.98$ & $0.21 \pm 0.051$ & $0.000^{* *}$ & $0.000^{* *}$ & $0.774^{\#}$ \\
\hline HOMA-B mean \pm SD & $36.84 \pm 24.91$ & $24.73 \pm 18.52$ & $38.29 \pm 68.03$ & $0.929^{\#}$ & $0.411^{\#}$ & $0.042^{*}$ \\
\hline QUICKI mean \pm SD & $2.66 \pm 0.087$ & $2.79 \pm 0.167$ & $2.9 \pm 0.126$ & $0.000^{* *}$ & $0.022^{*}$ & $0.005^{* *}$ \\
\hline $\begin{array}{l}\text { Vitamin D }(\mathrm{ng} / \mathrm{ml}) \\
\text { mean } \pm \mathrm{SD}\end{array}$ & $8.85 \pm 6.42$ & $10.83 \pm 5.45$ & $30.92 \pm 8.47$ & $0.000^{* *}$ & $0.000^{* *}$ & $0.220^{\#}$ \\
\hline $\mathrm{CRP}$ mean $\pm \mathrm{SD}$ & $41.15 \pm 37.03$ & $48.10 \pm 35.38$ & $13.89 \pm 20.78$ & $0.001^{* *}$ & $0.001^{* *}$ & $0.484^{\#}$ \\
\hline
\end{tabular}

Quantitative variables are expressed as mean \pm SD and compared using student t test. Categorical variables are expressed as percentage and compared using Chi square. FH = family history; BMI = body mass index; SBP = systolic blood pressure; DBP = diastolic blood pressure. IUFD = intra uterine fetal death; $\mathrm{Hb}=$ hemoglobin, WBCS = white b1lood cells, TG = triglycerides, T-Chol = total cholesterol, HDL-Chol = high density lipoprotein cholesterol, LDL-Chol = low density lipoprotein cholesterol, Ca = calcium. FBS = fasting blood sugar, HbA1c = glycated hemoglobin, HOMA-IR = homeostatic model assessment-insulin resistance. HOMA-B = homeostatic model assessment B cell function, QUICKI = Quantitative insulin sensitivity check index, CRP = C-reactive protein. ${ }^{*}=$ significant; ${ }^{* *}$ = highly significant; ${ }^{\#}=$ insignificant. 1) group I versus III, 2) group II versus III, 3) group I versus II.

found that Middle Eastern (64\%), black (58\%), Asian women (47\%), and Caucasian women (13\%) had a high prevalence of very poor vitamin D status (25 OH vit D $<25 \mathrm{nmol} / \mathrm{L}$. In Saudi Arabia, Ardawi et al. [21] reported 
Table 2. Correlation of 25 hydroxy vitamin D level with anthropomorphic and biochemical data of different study groups.

\begin{tabular}{|c|c|c|c|c|c|c|}
\hline \multirow{3}{*}{$\begin{array}{c}\text { Demographic and clinical } \\
\text { characters }\end{array}$} & \multicolumn{6}{|c|}{$25(\mathrm{OH}) \mathrm{D}$} \\
\hline & \multicolumn{2}{|c|}{ Group (1) GDM } & \multicolumn{2}{|c|}{ Group (2) Diabetic } & \multicolumn{2}{|c|}{ Group (3) Control } \\
\hline & $\mathbf{R}$ & $\mathbf{P}$ & $\mathbf{R}$ & $\mathbf{P}$ & $\mathbf{R}$ & $\mathbf{P}$ \\
\hline SBP (mmHg) & 0.123 & 0.449 & -0.099 & 0.679 & 0.180 & 0.461 \\
\hline DBP (mmHg) & -0.091 & 0.577 & -0.043 & 0.858 & 0.141 & 0.564 \\
\hline Pre preg BMI $\left(\mathrm{kg} / \mathrm{m}^{2}\right)$ & -0.623 & $0.000^{* *}$ & -0.256 & 0.276 & -0.159 & 0.516 \\
\hline TG (mg/dl) & 0.001 & 0.993 & 0.007 & 0.977 & -0.049 & 0.842 \\
\hline T-Cholesterol (mg/dl) & -0.001 & 0.997 & -0.468 & $0.038^{*}$ & -0.109 & 0.656 \\
\hline HDL-Cholesterol (mg/dl) & -0.117 & 0.474 & 0.102 & 0.668 & -0.124 & 0.613 \\
\hline LDL-Cholesterol (mg/dl) & 0.021 & 0.897 & -0.507 & $0.023^{*}$ & 0.027 & 0.912 \\
\hline Total Ca (mg/dl) & 0.169 & 0.297 & 0.026 & 0.914 & 0.662 & $0.002^{* *}$ \\
\hline Ionized Ca (mmol/l) & 0.362 & 0.0704 & 0.420 & 0.065 & 0.428 & 0.068 \\
\hline FBS (mg/dl) & -0.058 & 0.723 & -0.055 & 0.817 & 0.230 & 0.344 \\
\hline 1-hour glucose (mg/dl) & 0.067 & 0.681 & -0.172 & 0.469 & -0.015 & 0.953 \\
\hline 2-hour glucose (mg/dl) & 0.252 & 0.116 & -0.241 & 0.306 & 0.136 & 0.579 \\
\hline HbA1c (\%) & -0.124 & 0.446 & 0.188 & 0.469 & 0.204 & 0.402 \\
\hline Fasting insulin $(\mu \mathrm{u} / \mathrm{ml})$ & -0.597 & $0.05^{*}$ & -0.077 & 0.748 & 0.011 & 0.963 \\
\hline HOMA-IR & 0.202 & 0.211 & -0.095 & 0.691 & 0.108 & 0.661 \\
\hline HOMA-B & 0.271 & 0.091 & -0.050 & 0.840 & 0.090 & 0.713 \\
\hline QUICKI & -0.229 & 0.154 & -0.118 & 0.620 & 0.011 & 0.964 \\
\hline CRP & -0.059 & 0.716 & -0.610 & $0.004^{* *}$ & 0.054 & 0.826 \\
\hline
\end{tabular}

BMI = body mass index; SBP = systolic blood pressure; DBP = diastolic blood pressure. IUFD = intra uterine fetal death. Hb = hemoglobin, WBCS = white b1lood cells, TG = triglycerides, T-Chol $=$ total cholesterol, HDL-Chol $=$ high density lipoprotein cholesterol, LDL-Chol $=$ low density lipoprotein cholesterol, $\mathrm{Ca}=$ calcium. FBS = fasting blood sugar, HbA1c = glycated hemoglobin, HOMA-IR = homeostatic model assessment-insulin resistance. HOMA-B = homeostatic model assessment B cell function, QUICKI = Quantitative insulin sensitivity check index, CRP = C-reactive protein.

Table 3. Correlation of HOMA-IR with some metabolic risk factors in the study groups.

\begin{tabular}{|c|c|c|c|c|c|c|}
\hline \multirow{3}{*}{$\begin{array}{c}\text { Demographic and clinical } \\
\text { characters }\end{array}$} & \multicolumn{6}{|c|}{ HOMA-IR } \\
\hline & \multicolumn{2}{|c|}{ Group (1) GDM } & \multicolumn{2}{|c|}{ Group (2) Diabetic } & \multicolumn{2}{|c|}{ Group (3) Control } \\
\hline & $\mathbf{R}$ & $\mathbf{P}$ & $\mathbf{R}$ & $\mathbf{P}$ & $\mathbf{R}$ & $\mathbf{P}$ \\
\hline SBP (mmHg) & 0.110 & 0.500 & -0.288 & 0.218 & 0.031 & 0.900 \\
\hline DBP (mmHg) & 0.152 & 0.350 & -0.140 & 0.555 & 0.211 & 0.387 \\
\hline FBS (mg/dl) & 0.291 & $0.050^{*}$ & 0.538 & $0.014^{*}$ & 0.114 & 0.644 \\
\hline 1 hour glucose (mg/dl) & 0.142 & 0.382 & 0.242 & 0.304 & 0.354 & 0.137 \\
\hline 2 hour glucose (mg/dl) & 0.339 & $0.032^{*}$ & 0.180 & 0.449 & 0.199 & 0.414 \\
\hline HbA1c (\%) & 0.104 & 0.522 & -0.023 & 0.923 & -0.547 & $0.015^{*}$ \\
\hline CRP & -0.110 & 0.499 & -0.078 & 0.745 & -0.116 & 0.636 \\
\hline Pre preg BMI $\left(\mathrm{kg} / \mathrm{m}^{2}\right)$ & -0.088 & 0.589 & -0.137 & 0.566 & 0.075 & 0.759 \\
\hline
\end{tabular}

BMI = body mass index; IUFD = intra uterine fetal death. SBP = systolic blood pressure; DBP $=$ diastolic blood pressure. ${ }^{*}=$ significant; $^{* *}=$ highly

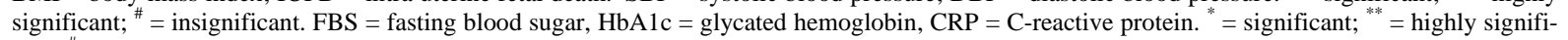
cant; ${ }^{\#}$ = insignificant. 
Table 4. The relative risk of some potential risk factors other than vitamin D for development of gestational diabetes in relation to control.

\begin{tabular}{ccc}
\hline & OR (95\%CI) & P value \\
\hline Age & $0.93(0.84-1.03)$ & 0.150 \\
SBP & $1.07(1.03-1.11)$ & $0.002^{*}$ \\
DBP & $1.06(1.01-1.11)$ & $0.021^{*}$ \\
TG & $1.04(1.02-1.07)$ & $0.001^{*}$ \\
TC & $1.21(1.04-1.41)$ & $0.015^{*}$ \\
HDL & $0.96(0.92-1.001)$ & 0.055 \\
LDL & $1.17(1.04-1.3)$ & $0.007^{*}$ \\
BMI & $1.93(1.34-2.76)$ & $<0.001^{*}$ \\
CRP & $1.04(1.01-1.07)$ & $0.013^{*}$ \\
\hline
\end{tabular}

$\mathrm{CI}$, confidence interval, $\mathrm{OR}$; Odds ratio, $\mathrm{BMI}=$ body mass index; $\mathrm{SBP}=$ systolic blood pressure; $\mathrm{DBP}=$ diastolic blood pressure. $\mathrm{TG}=$ triglycerides, T-Chol = total cholesterol, HDL-Chol = high density lipoprotein cholesterol, LDL-Chol = low density lipoprotein cholesterol.

Table 5. The sensitivity, specificity, positive predictive value and negative predictive value of $25 \mathrm{OH}$ vitamin D level in diagnosis of GDM versus control group.

\begin{tabular}{cccccccc}
\hline Cut of point & AUC & Sensitivity & Specificity & PPV & NPV & Accuracy & P value \\
\hline$\leq 22$ & 0.975 & 97.5 & 90 & 95.1 & 94.7 & $95 \%$ & $<0.001^{*}$ \\
\hline
\end{tabular}

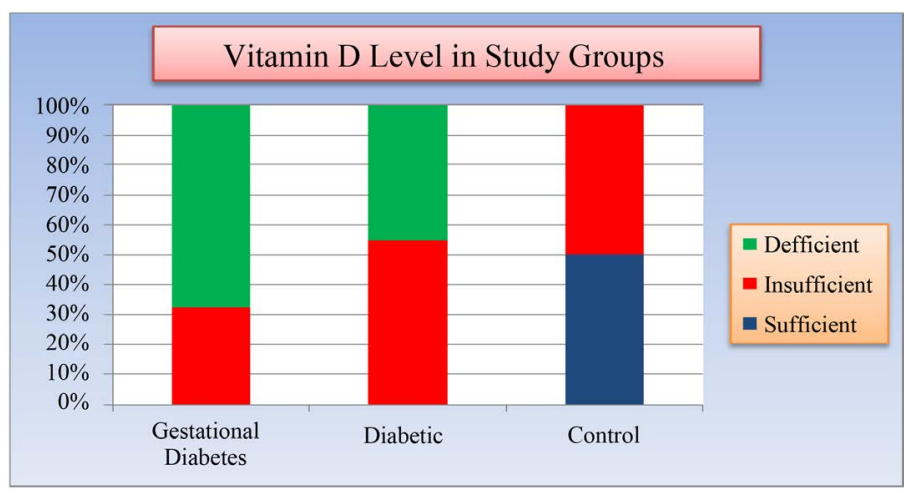

Figure 1. Histogram showing the mean serum levels of serum vitamin D in study groups.

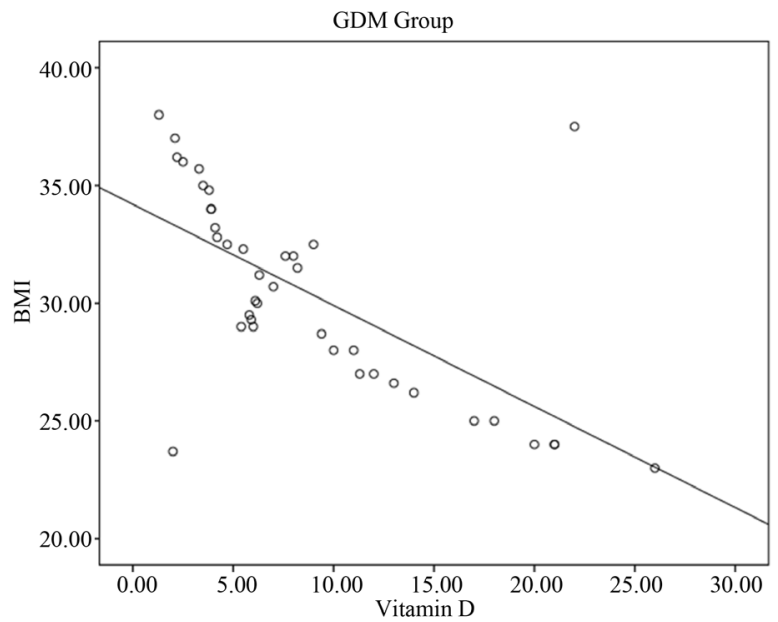

Figure 2. Relation between BMI and vit D level in GDM group. 


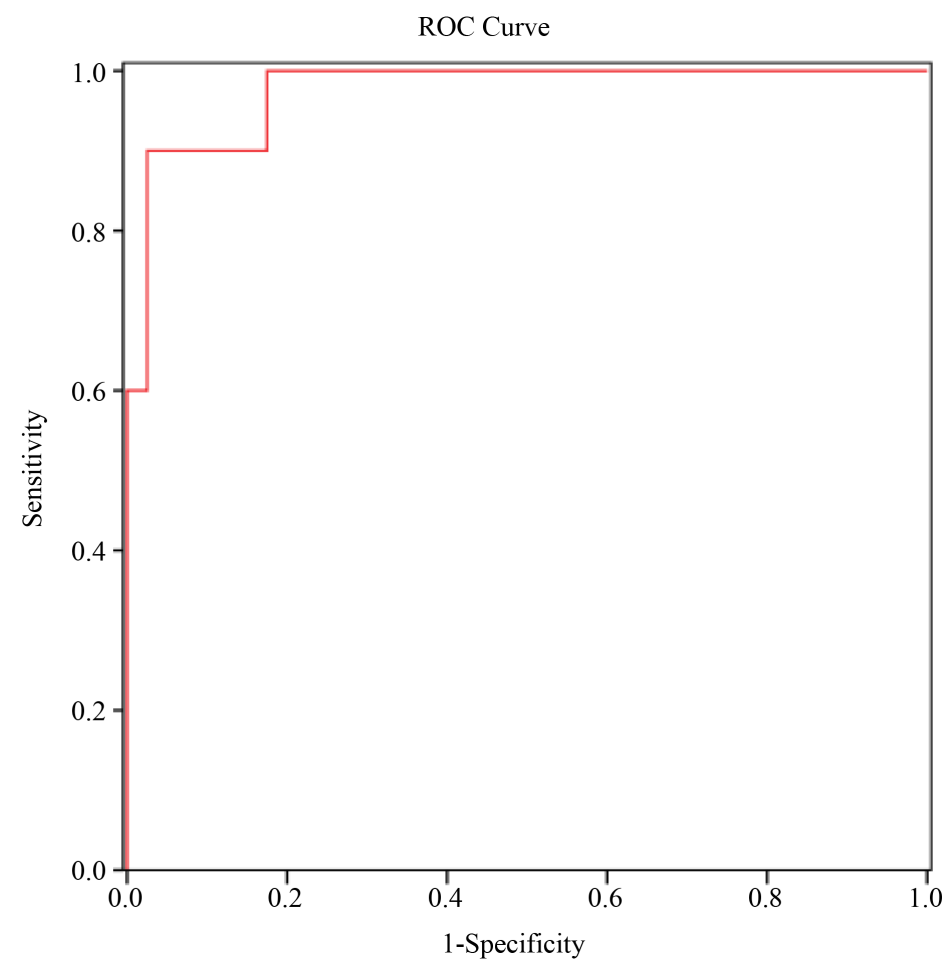

Figure 3. Receiver operating characteristic (ROC) plots curve for $25 \mathrm{OH}$ vitamin D level in the GDM and control groups. Mean of area under ROC curve for $25 \mathrm{OH}$ vitamin D was (0.97), CI $(0.95 \%)$, P-value $=0.0001)$.

high prevalence (72\%) of vitamin D deficiency among Saudi women of childbearing age.

Vit D deficiency may predispose to glucose intolerance, altered insulin secretion and type 2 diabetes [22]-[24] either directly via vit D receptor (VDR) activation, indirectly via calcemic hormones, or via inflammation [25]. The presence of VDR in the pancreatic B cells suggests an endocrine role of vitamin D in GDM may be through augmenting insulin secretion and insulin sensitivity [26].

In concordance with several cross-sectional studies, the present study reported an association between low maternal vitamin D status and GDM. Group I and II have low serum vitamin D levels in comparison with control with more deficiency in GDM group. The mean levels were 8.8, 10.8 and $30.9 \mathrm{ng} / \mathrm{ml}$ respectively). A cutoff point for vit $\mathrm{D}$ serum level in prediction of GDM was determined by application of receiver operating characteristic (ROC) curve. It was found to be at a level of $22 \mathrm{ng} / \mathrm{ml}$ with a sensitivity of $97.5 \%$ and a specificity of $90 \%$ $(\mathrm{P}=0.00)$.

There is a complex relationship between vitamin D and obesity. While our and other many studies [27]-[34] reported an inverse relation between vit D levels and BMI to the extent of considering it as a strong predictor of vit D [27] [28] [33] little studies found no significant association between vitamin D and BMI [35] [36].

Some authors [37] [38] reported that alteration of the vitamin D in obese subjects is characterized by secondary hyperparathyroidism which may be associated with enhanced renal tubular reabsorption of calcium and increased circulating $1.25(\mathrm{OH}) 2 \mathrm{D}$ which may cause a feedback inhibition of $25(\mathrm{OH}) \mathrm{D}$ synthesis. This feedback was a matter of doubt in other studies [39] [40]. We agree with Torloni et al. [41] in that the risk of GDM is positively associated with pre pregnancy BMI. We found an inverse association between serum 25OHD and BMI in patients with GDM $(P=0.00)$. The logistic regression analysis $(\mathrm{LRA})$ revealed that the risk of GDM increases by 1.93 times more with increase BMI.

In agreement with Farrant et al. [42], the present study showed no association between vitamin D serum level and HbA1c. Despite this, other studies [43]-[45] showed a potential interaction between 25 (OH) D and blood glucose control in pregnancy.

In agreement with [46], we found that vitamin $\mathrm{D}$ had significant negative association with fasting insulin $(\mathrm{P}=$ 
$0.05)$ and tendency towards significant positive association with (HOMA-B) $(\mathrm{P}=0.09)$ in GDM group. According to de Souza et al. and Holick et al. [47] [48], vit D is required for normal insulin secretion.

A number of studies [49] [50] revealed that 25OHD levels in non-pregnant women were positive correlated with insulin sensitivity and that higher 25OHD levels were associated with a lower risk of IGT and T2DM. They concluded a positive correlation between 25OHD levels and insulin sensitivity. This may be explained by the importance of vit $\mathrm{D}$ for helping $\beta$-cells of the pancreas to keep up with growing insulin demand. Also, it helps the parafollicular cells of the thyroid gland to produce calcitonin, the hormone that moves calcium into the tissues. Calcitonin triggers the release of insulin from the $\beta$-cell "pockets" in which it is stored, keeping up with the greater demand for insulin by mother and developing child [51]. The placenta has a capacity to synthesize active $1,25(\mathrm{OH}) 2 \mathrm{D}$ which is linked to the immune-modulatory function of the placenta in humans [52].

Maghbooli et al. [35] investigated the relationship between serum 25-OH vit D and insulin resistance, using the HOMA equation. They found increased vit D deficiency in the GDM group than in the IGT and normal groups (44\%, 33\%, and 23\%, respectively). Daniel and Keller [53] reported that lower levels of 25OHD were associated with an increased risk of GDM by $40 \%$ for each one standard deviation (SD) decrease in $25 \mathrm{OH}$ Vit D level (odds ratio, 1.40/1 SD) [95\% CI, P = 0.04]. In the present study, we could not document any association between hypovitaminosis D and HOMA-IR. This may be explained by the different ethnicity or the small-sized study sample. Ethnicity was considered as a risk factor for altered vitamin D status and may independently affect the association between 25OHD levels and the risk of diabetes [18]. Clifton-Bligh et al. [54] reported that serum 25-hydroxyvitamin D was negatively correlated with fasting plasma glucose, fasting insulin, and insulin resistance (calculated by HOMA-IR) which was statistically insignificant. Maghbooli et al. [35] who found that HOMA-IR $\geq 3$ (indicative of insulin resistance) in those with vitamin D deficiency more than in those with normal vitamin D. Also, Wang et al. [44] reported that low vitamin D levels were associated with increased the risk of GDM and high serum 25OHD levels were associated with reduced risk of insulin resistance. After adjusting for ethnicity, age and BMI, Joergensen et al. [45] reported inverse correlation between $25(\mathrm{OH}) \mathrm{D}$ and fasting glucose, insulin and HOMA-IR index. The relationship with glucose retained borderline significance.

In the Third National Health and Nutrition Examination Survey (NHANES III) and a meta-analysis of crosssectional studies, serum 25OHD levels were found to be inversely associated with the risk of diabetes in nonHispanic whites and Mexican Americans, but not in non-Hispanic blacks [22] [50].

Borissova et al. [55] evaluated the effects of vitamin D3 supplementation on insulin secretion and insulin resistance in 10 women with T2DM. Administration of 1332 IU/day cholecalciferol for 1 month significantly increased plasma 25OHD levels and increased first-phase insulin secretion during an intravenous glucose tolerance test.

In agreement with Pradhan et al. [56], the present study supports the inflammatory role in pathogenesis of type $2 \mathrm{DM}$ as we found a significant increase in C-reactive protein (CRP) in the patient groups (gestational and pre gestational) in comparison to the control group $(\mathrm{P}=0.00)$. Gregor and Hotamisligil [57] reported that insulin binding to its receptor triggers tyrosine phosphorylation of insulin receptor substrates (IRS). Inflammatory signals can target IRS-1 for serine phosphorylation, which inhibits the insulin receptor signaling cascade [58]. In the present study, there was an inverse correlation between hypovitaminosis D and CRP as an inflammatory marker in the diabetic groups $(\mathrm{P}=0.00)$ as vit $\mathrm{D}$ played an important role in the modulation of inflammatory response. Also, some cross-sectional studies indicate that hypovitaminosis D is associated with higher serum levels of inflammatory biomarkers, such as CRP in healthy [59], and in obese subjects [60]. But, this could not be confirmed these findings [33] [61].

\section{Conclusion}

Although it might seem premature to draw a sharp relation between hypovitaminosis D and GDM, this study showed the importance of vit D in GDM, the need for supplementation below $22 \mathrm{ng} / \mathrm{ml}$, and the role of hypovitaminosis D in increasing insulin resistance. Further randomized studies with vit D supplementation are recommended.

\section{References}

[1] Forouhi, N.G., Luan, J., Cooper, A., Boucher, B.J. and Wareham, N.J. (2008) Baseline Serum 25-Hydroxy Vitamin D Is Predictive of Future Glycemic Status and Insulin Resistance: the Medical Research Council Ely Prospective Study 1990-2000. Diabetes, 57, 2619-2625. http://dx.doi.org/10.2337/db08-0593 
[2] Kositsawat, J., Freeman, V.L., Gerber, B.S. and Geraci, S. (2010) Association of A1C Levels with Vitamin D Status in U.S. Adults: Data from the National Health and Nutrition Examination Survey. Diabetes Care, 33, 1236-1238. http://dx.doi.org/10.2337/dc09-2150

[3] Association, A.D. (2014) Standards of Medical Care in Diabetes-2014. Diabetes Care, 37, S14-S80. http://dx.doi.org/10.2337/dc14-S014

[4] Reece, E.A., Leguizamon, G. and Wiznitzer, A. (2009) Gestational Diabetes: The Need for a Common Ground. The Lancet, 373, 1789-1797. http://dx.doi.org/10.1016/S0140-6736(09)60515-8

[5] Mezza, T.L., Muscogiuri, G., Sorice, G.P., Prioletta, A., Salomone, E., Pontecorvi, A. and Giaccari, A. (2012) Vitamin D Deficiency: A New Risk Factor for Type 2 Diabetes? Annals of Nutrition and Metabolism, 61, 337-348. http://dx.doi.org/10.1159/000342771

[6] Burris, H.H. and Camargo Jr., C.A. (2014) Vitamin D and Gestational Diabetes Mellitus. Current Diabetes Reports, 14, 451. http://dx.doi.org/10.1007/s11892-013-0451-3

[7] Marwaha, R., Tandon, N., Chopra, S., Agarwal, N., Garg, M., Sharma, B., Kanwar, R., Bhadra, K., Singh, S. and Mani, K. (2011) Vitamin D Status in Pregnant Indian Women across Trimesters and Different Seasons and Its Correlation with Neonatal Serum 25-Hydroxyvitamin D Levels. British Journal of Nutrition, 106, 1383-1389. http://dx.doi.org/10.1017/S000711451100170X

[8] Perampalam, S., Ganda, K., CHOW, K.A., Opie, N., Hickman, P.E., Shadbolt, B., Hennessy, A., Grunstein, H. and Nolan, C.J. (2011) Vitamin D Status and Its Predictive Factors in Pregnancy in 2 Australian Populations. Australian and New Zealand Journal of Obstetrics and Gynaecology, 51, 353-359. http://dx.doi.org/10.1111/j.1479-828X.2011.01313.x

[9] Tao, M., Shao, H., Gu, J. and Zhen, Z. (2012) Vitamin D Status of Pregnant Women in Shanghai, China. Journal of Maternal-Fetal \& Neonatal Medicine, 25, 237-239. http://dx.doi.org/10.3109/14767058.2011.569613

[10] Sääf, M., Fernell, E., Kristiansson, F., Barnevik Olsson, M., Gustafsson, S.A. and Bågenholm, G. (2011) Severe Vitamin D Deficiency in Pregnant Women of Somali Origin Living in Sweden. Acta Paediatrica, 100, 612-614. http://dx.doi.org/10.1111/j.1651-2227.2011.02134.x

[11] Shibata, M., Suzuki, A., Sekiya, T., Sekiguchi, S., Asano, S., Udagawa, Y. and Itoh, M. (2011) High Prevalence of Hypovitaminosis D in Pregnant Japanese Women with Threatened Premature Delivery. Journal of Bone and Mineral Metabolism, 29, 615-620. http://dx.doi.org/10.1007/s00774-011-0264-X

[12] Aghajafari, F., Nagulesapillai, T., Ronksley, P.E., Tough, S.C., O’Beirne, M. and Rabi, D.M. (2013) Association between Maternal Serum 25-Hydroxyvitamin D Level and Pregnancy and Neonatal Outcomes: Systematic Review and Meta-Analysis of Observational Studies. British Medical Journal (Clinical Research Ed.), 346, f1169.

[13] Senti, J., Thiele, D.K. and Anderson, C.M. (2012) Maternal Vitamin D Status as a Critical Determinant in Gestational Diabetes. Journal of Obstetric Gynecologic \& Neonatal Nursing, 41, 328-338. http://dx.doi.org/10.1111/j.1552-6909.2012.01366.x

[14] Rudnicki, P. and Mølsted-Pedersen, L. (1997) Effect of 1, 25-Dihydroxycholecalciferol on Glucose Metabolism in Gestational Diabetes Mellitus. Diabetologia, 40, 40-44. http://dx.doi.org/10.1007/s001250050640

[15] Baker, A.M., Haeri, S., Camargo Jr., C.A., Stuebe, A.M. and Boggess, K.A. (2012) First-Trimester Maternal Vitamin D Status and Risk for Gestational Diabetes (GDM): A Nested Case-Control Study. Diabetes/Metabolism Research and Reviews, 28, 164-168. http://dx.doi.org/10.1002/dmrr.1282

[16] Farrant, H.J., Krishnaveni, G.V., Hill, J.C., Boucher, B.J., Fisher, D.J., Noonan, K., Osmond, C., Veena, S.R. and Fall, C.H. (2009) Vitamin D Insufficiency Is Common in Indian Mothers but Is Not Associated with Gestational Diabetes or Variation in Newborn Size. European Journal of Clinical Nutrition, 63, 646-652. http://dx.doi.org/10.1038/ejcn.2008.14

[17] Burris, H.H. and Camargo Jr., C.A. (2011) Vitamin D and Gestational Diabetes Mellitus. Current Diabetes Reports, 14, 451. http://dx.doi.org/10.1007/s11892-013-0451-3

[18] Zhang, C., Qiu, C., Hu, F.B., David, R.M., Van Dam, R.M., Bralley, A. and Williams, M.A. (2008) Maternal Plasma 25-Hydroxyvitamin D Concentrations and the Risk for Gestational Diabetes Mellitus. PLoS ONE, 3, e3753. http://dx.doi.org/10.1371/journal.pone.0003753

[19] Holmes, V.A., Barnes, M.S., Alexander, H.D., McFaul, P. and Wallace, J.M.W. (2009) Vitamin D Deficiency and Insufficiency in Pregnant Women: A Longitudinal Study. British Journal of Nutrition, 102, 876-881. http://dx.doi.org/10.1017/S0007114509297236

[20] Yu, C.K., Sykes, L., Sethi, M., Teoh, T.G. and Robinson, S. (2009) Vitamin D Deficiency and Supplementation during Pregnancy. Clinical Endocrinology, 70, 685-690. http://dx.doi.org/10.1111/j.1365-2265.2008.03403.x

[21] Ardawi, M.S., Al-Sibiany, A.M., Bakhsh, T.M., Rouzi, A.A. and Qari, M.H. (2011) Vitamin D Status in Relation to Obesity, Bone Mineral Density, Bone Turnover Markers and Vitamin D Receptor Genotypes in Healthy Saudi Pre- and 
Postmenopausal Women. Osteoporosis International, 22, 463-475. http://dx.doi.org/10.1007/s00198-010-1249-7

[22] Pittas, A.G., Sun, Q., Manson, J.E., Dawson-Hughes, B. and Hu, F.B. (2010) Plasma 25-Hydroxyvitamin D Concentration and Risk of Incident Type 2 Diabetes in Women. Diabetes Care, 33, 2021-2023. http://dx.doi.org/10.2337/dc10-0790

[23] Chagas, C., Borges, M., Martini, L. and Rogero, M. (2012) Focus on Vitamin D, Inflammation and Type 2 Diabetes. Nutrients, 4, 52-67. http://dx.doi.org/10.3390/nu4010052

[24] Lim, S., Kim, M.J., Choi, S.H., Shin, C.S., Park, K.S., Jang, H.C., Billings, L.K. and Meigs, J.B. (2013) Association of Vitamin D Deficiency with Incidence of Type 2 Diabetes in High-Risk Asian Subjects. The American Journal of Clinical Nutrition, 97, 524-530. http://dx.doi.org/10.3945/ajcn.112.048496

[25] Thorand, B., Zierer, A., Huth, C., Linseisen, J., Meisinger, C., Roden, M., Peters, A., Koenig, W. and Herder, C. (2011) Effect of Serum 25-Hydroxivitamin D on Risk for Type 2 Diabetes May Be Partially Mediated by Subclinical Inflammation: Results from the MONICA/RORA, Ausburg Study. Diabetes Care, 34, 2320-2322. http://dx.doi.org/10.2337/dc11-0775

[26] Thacher, T.D. and Clarke, B.L. (2011) Vitamin D Insufficiency. Mayo Clinic Proceedings, 86, 50-60. http://dx.doi.org/10.4065/mcp.2010.0567

[27] Wortsman, J., Matsuoka, L.Y., Chen, T.C., Lu, Z. and Holick, M.F. (2000) Decreased Bioavailability of Vitamin D in Obesity. The American Journal of Clinical Nutrition, 72, 690-693.

[28] Ford, E.S., Ajani, U.A., McGuire, L.C. and Liu, S. (2005) Concentrations of Serum Vitamin D and the Metabolic Syndrome among US Adults. Diabetes Care, 28, 1228-1230. http://dx.doi.org/10.2337/diacare.28.5.1228

[29] Hyppönen, E. and Power, C. (2006) Vitamin D Status and Glucose Homeostasis in the 1958 British Birth Cohort: The Role of Obesity. Diabetes Care, 29, 2244-2246. http://dx.doi.org/10.2337/dc06-0946

[30] Florez, H., Martinez, R., Chacra, W., Strickman-Stein, N. and Levis, S. (2007) Outdoor Exercise Reduces the Risk of Hypovitaminosis D in the Obese. The Journal of Steroid Biochemistry and Molecular Biology, 103, 679-681. http://dx.doi.org/10.1016/j.jsbmb.2006.12.032

[31] Lee, P., Greenfield, J.R., Seibel, M.J., Eisman, J.A. and Center, J.R. (2009) Adequacy of Vitamin D Replacement in Severe Deficiency Is Dependent on Body Mass Index. American Journal of Medicine, 122, 1056-1060. http://dx.doi.org/10.1016/j.amjmed.2009.06.008

[32] Young, K.A., Engelman, C.D., Langefeld, C.D., Hairston, K.G., Haffner, S.M., Bryer-Ash, M. and Norris, J.M. (2009) Association of Plasma Vitamin D Levels with Adiposity in Hispanic and African Americans. Journal of Clinical Endocrinology \& Metabolism, 94, 3306-3313. http://dx.doi.org/10.1210/jc.2009-0079

[33] Vilarrasa, N., Vendrell, J., Maravall, J., Elío, I., Solano, E., San José, P., García, I., Virgili, N., Soler, J. and Gómez, J.M. (2010) Is Plasma 25(OH) D Related to Adipokines, Inflammatory Cytokines and Insulin Resistance in Both a Healthy and Morbidly Obese Population? Endocrine, 38, 235-242. http://dx.doi.org/10.1007/s12020-010-9379-4

[34] Angelico, F., Del Ben, M., Baroni, M.G., Pozzilli, P., Morini, S. and Cavallo, M.G. (2011) Strong Association between Non-Alcoholic Fatty Liver Disease (NAFLD) and Low $25(\mathrm{OH})$ Vitamin D Levels in an Adult Population with Normal Serum Liver Enzymes. BMC Medicine, 9, 85. http://dx.doi.org/10.1186/1741-7015-9-85

[35] Maghbooli, Z., Hossein-Nezhad, A., Karimi, F., Shafaei, A.R. and Larijani, B. (2008) Correlation between Vitamin D3 Deficiency and Insulin Resistance in Pregnancy. Diabetes/Metabolism Research and Reviews, 24, 27-32. http://dx.doi.org/10.1002/dmrr.737

[36] Soheilykhah, S., Mojibian, M., Rashidi, M., Rahimi-Saghand, S. and Jafari, F. (2010) Maternal Vitamin D Status in Gestational Diabetes Mellitus. Nutrition in Clinical Practice, 25, 524-527. http://dx.doi.org/10.1177/0884533610379851

[37] Vilarrasa, N., Maravall, J., Estepa, A., Sánchez, R., Masdevall, C., Navarro, M.A., Alía, P., Soler, J. and Gómez, J.M. (2007) Low 25-Hydroxyvitamin D Concentrations in Obese Women: Their Clinical Significance and Relationship with Anthropometric and Body Composition Variables. Journal of Endocrinological Investigation, 30, 653-658. http://dx.doi.org/10.1007/bf03347445

[38] Yildizhan, R., Kurdoglu, M., Adali, E., Kolusari, A., Yildizhan, B., Sahin, H.G. and Kamaci, M. (2009) Serum 25-Hydroxyvitamin D Concentrations in Obese and Non-Obese Women with Polycystic Ovary Syndrome. Archives of Gynecology and Obstetrics, 280, 559-563. http://dx.doi.org/10.1007/s00404-009-0958-7

[39] Parikh, S.J., Edelman, M., Uwaifo, G.I., Freedman, R.J., Semega-Janneh, M., Reynolds, J. and Yanovski, J.A. (2004) The Relationship between Obesity and Serum 1, 25-Dihydroxy Vitamin D Concentrations in Healthy Adults. Journal of Clinical Endocrinology \& Metabolism, 89, 1196-1199. http://dx.doi.org/10.1210/jc.2003-031398

[40] Konradsen, S., Ag, H., Lindberg, F., Hexeberg, S. and Jorde, R. (2008) Serum 1,25-Dihydroxy Vitamin D Is Inversely Associated with Body Mass Index. European Journal of Nutrition, 47, 87-91. 
http://dx.doi.org/10.1007/s00394-008-0700-4

[41] Torloni, M.R., Betrán, A.P., Horta, B.L., Nakamura, M.U., Atallah, A.N., Moron, A.F. and Valente, O. (2009) Prepregnancy BMI and the Risk of Gestational Diabetes: A Systematic Review of the Literature with Meta-Analysis. Obesity Reviews, 10, 194-203.

[42] Farrant, H.J., Krishnaveni, G.V., Hill, J.C., Boucher, B.J., Fisher, D.J., Noonan, K., Osmond, C., Veena, S.R. and Fall, C.H. (2009) Vitamin D Insufficiency Is Common in Indian Mothers but Is Not Associated with Gestational Diabetes or Variation in Newborn Size. European Journal of Clinical Nutrition, 63, 646-652. http://dx.doi.org/10.1038/ejcn.2008.14

[43] Lau, S.L., Gunton, J.E., Athayde, N.P., Byth, K. and Cheung, N.W. (2011) Serum 25-Hydroxyvitamin D and Glycated Haemoglobin Levels in Women with Gestational Diabetes Mellitus. Medical Journal of Australia, 194, 334-337.

[44] Wang, O., Nie, M., Hu, Y.Y., Zhang, K., Li, W., Ping, F., Liu, J.T., Chen, L.M. and Xing, X.P. (2012) Association between Vitamin D Insufficiency and the Risk for Gestational Diabetes Mellitus in Pregnant Chinese Women. Biomedical and Environmental Sciences, 25, 399-406.

[45] Joergensen, J.S., Lamont, R.F. and Torloni, M.R. (2014) Vitamin D and Gestational Diabetes. Current Opinion in Clinical Nutrition \& Metabolic Care, 17, 360-367. http://dx.doi.org/10.1097/MCO.0000000000000064

[46] Rudnicki, P.M. and Molsted-Pedersen, L. (1997) Effect of 1,25 Dihydroxy Cholecalciferol on Glucose Metabolism in Gestational Diabetes Mellitus. Diabetologia, 40, 40-44. http://dx.doi.org/10.1007/s001250050640

[47] de Souza, S.R. and Vianna, L.M. (2005) Effect of Cholecalciferol Supplementation on Blood Glucose in an Experimental Model of Type 2 Diabetes Mellitus in Spontaneously Hypertensive Rats and Wistar Rats. Clinica Chimica Acta, 358, 146-150. http://dx.doi.org/10.1016/j.cccn.2005.02.020

[48] Holick, M.F. (2007) Vitamin D Deficiency. The New England Journal of Medicine, 357, 266-281. http://dx.doi.org/10.1056/NEJMra070553

[49] Chiu, K.C., Chu, A., Go, V.L. and Saad, M.F. (2004) Hypovitaminosis D Is Associated with Insulin Resistance and Beta Cell Dysfunction. The American Journal of Clinical Nutrition, 79, 820-825.

[50] Scragg, R., Sowers, M. and Bell, C. (2004) Serum 25-Hydroxyvitamin D, Diabetes, and Ethnicity in the Third National Health and Nutrition Examination Survey. Diabetes Care, 27, 2813-2818. http://dx.doi.org/10.2337/diacare.27.12.2813

[51] Arora, C.P. and Hobel, C.J. (2010) Vitamin D_A Novel Role in Pregnancy. Biopolymers and Cell, 26, 97-104. http://dx.doi.org/10.7124/bc.00014B

[52] Evans, K.N., Bulmer, J.N., Kilby, M.D. and Hewison, M. (2004) Vitamin D and Placental-Decidual Function. Journal of the Society for Gynecologic Investigation, 11, 263-271. http://dx.doi.org/10.1016/j.jsgi.2004.02.002

[53] Daniel, M. and Keller, D. (2012) Low First-Trimester Vitamin D Predicts Gestational Diabetes.

[54] Clifton-Bligh, R.J., McElduff, P. and McElduff, A. (2008) Maternal Vitamin D Deficiency, Ethnicity and Gestational Diabetes. Diabetic Medicine, 25, 678-684. http://dx.doi.org/10.1111/j.1464-5491.2008.02422.x

[55] Borissova, A.M., Tankova, T., Kirilov, G., Dakovska, L. and Kovacheva, R. (2003) The Effect of Vitamin D3 on Insulin Secretion and Peripheral Insulin Sensitivity in Type 2 Diabetic Patients. International Journal of Clinical Practice, 57, 258-261.

[56] Pradhan, A. (2007) Obesity, Metabolic Syndrome, and Type 2 Diabetes: Inflammatory Basis of Glucose Metabolic Disorders. Nutrition Reviews, 65, S152-S156. http://dx.doi.org/10.1301/nr.2007.dec.S152-S156

[57] Gregor, M.F. and Hotamisligil, G.S. (2011) Inflammatory Mechanisms in Obesity. Annual Review of Immunology, 29, 415-445. http://dx.doi.org/10.1146/annurev-immunol-031210-101322

[58] Zeyda, M. and Stulnig, T.M. (2009) Obesity, Inflammation, and Insulin Resistance: A Mini-Review. Gerontology, 55, 379-386. http://dx.doi.org/10.1159/000212758

[59] Ngo, D.T., Sverdlov, A.L., McNeil, J.J. and Horowitz, J.D. (2010) Does Vitamin D Modulate Asymmetric Dimethylarginine and C-Reactive Protein Concentrations? American Journal of Medicine, 123, 335-341. http://dx.doi.org/10.1016/j.amjmed.2009.09.024

[60] Bellia, A., Garcovich, C., D’Adamo, M., Lombardo, M., Tesauro, M., Donadel, G., Gentileschi, P., Lauro, D., Federici, M., Lauro, R. and Sbraccia, P. (2013) Serum 25-Hydroxyvitamin D Levels Are Inversely Associated with Systemic Inflammation in Severe Obese Subjects. Internal and Emergency Medicine, 8, 33-40.

[61] Ganji, V., Zhang, X., Shaikh, N. and Tangpricha, V. (2011) Serum 25-Hydroxyvitamin D Concentrations Are Associated with Prevalence of Metabolic Syndrome and Various Cardiometabolic Risk Factors in US Children and Adolescents Based on Assay-Adjusted Serum 25-Hydroxyvitamin D Data from NHANES 2001-2006. The American Journal of Clinical Nutrition, 94, 225-233. http://dx.doi.org/10.3945/ajcn.111.013516 